\title{
Decision-Making Tool for Cost- Efficient and Environmentally Friendly Wood Mobilisation
}

\author{
Matevž Triplat ${ }^{1}$, Peter Prislan ${ }^{1}$, Nike Krajnc ${ }^{1}$
}

1 Slovenian Forestry Institute, Department for Forest Techniques and Economics, Večna pot 2, SI-1000 Ljubljana, Slovenia

$\triangle$ Corresponding author: e-mail: matevz.triplat@gozdis.si

Citation:

TRIPLAT M, PRISLAN P, KRAJNC N 2015 Decision-Making Tool for Cost-Efficient and Environmentally Friendly Wood Mobilisation. South-east Eur for 6 (2): 179-190. DOI: http://dx.doi.org/10.15177/seefor.15-16

\section{Abstract}

Background and Purpose: With development of forest management technologies, the efficiency of wood production was significantly improved, and thus the impact on forests has changed as well. The article presents a practical decision-making tool for selection of most suitable harvesting system, considering given terrain as well as expected soil conditions on harvesting sites. The decision-making tool should support cost-efficient and environmentally friendly mobilisation of wood.

Materials and Methods: The presented decision-making tool is based on ground bearing capacities (relevant environmental parameter) and nominal ground pressure (harvesting system characteristics). Soil and terrain (slope) characteristics were taken into account for selection of the most suitable harvesting system. Three-step methodological approach was suggested, where soil and terrain conditions were defined in first step, while harvesting system were described using wood process charts ("functiogramms") in second step. In final step ecological and technological requirements were matched.

Results: To exemplify the three-step methodology, a decision-making tool was prepared for the three selected harvesting systems. The proposed harvesting systems differ in technological, ecological and economic aspects, but each is limited by at least one of the aspect.

Conclusions: The decision-making tool in combination with the presented wood process charts ("functiogramms") can simplify and facilitate forest production planning, although it can also be used in case of unforeseen event e.g. changing of soil moisture, machinery failure and insufficient current capacities. Considering the envisaged quantities and types of forest wooden assortments, it is possible to use the decision-making tool for a basic selection of most appropriate harvesting systems. The main idea behind the suggested three step methodological approach is that forest workers can prepare individual decision-making matrix (based on ecological and technological parameters such as technical or economical limitations of harvesting machines).

Keywords: decision support model, soil-machinery interaction, terrain conditions, wood process charts, forest operations 


\section{INTRODUCTION}

Over the last few decades, the exploitation of new technological solution in the field of round wood production has increased. This has resulted in a massive effort towards forest mechanization. Harvesters, processors and forwarders have become widespread in all industrialized countries not only in Slovenia, but also in other parts of the South-east European (SEE) region, far beyond the borders of the Nordic countries where they were first developed and thoroughly studied [1-4]. In general, perception about modern harvesting systems is related with high productivity and cost efficiency on the one hand and with heavy machinery causing severe ecological implications to the stand (i.e. wounding of trees and devaluation of wood quality) and soil (e.g. soil compaction, erosion, mixing of soil horizons, etc.) on the other hand [5]. Due to the vast amount and range of available harvesting systems, operators (foresters) often select less suitable harvesting solutions for the particular stand/site, with negative ecological and environmental consequences $[6,7]$. Thus, enhances a negative general opinion about modern harvesting systems.

Magagnotti et al. [2] investigated the impact of conventional motor-manual and fully-mechanised thinning on Mediterranean pine plantations and concluded that properly applied fully-mechanised harvesting does not cause heavier soil impacts than traditional motor-manual harvesting; in addition, it results in much lower stand damage. Magagnotti et al. [3] also performed a study on salvage harvesting after forest wind-throw, using a versatile fully mechanised system; the results showed moderate soil compaction and unlikely adverse effects on advanced regeneration.

Selection of harvesting systems can depend on different preconditions which can be divided in three major groups: (i) terrain properties, (ii) extent of environmental impacts and (iii) production costs. In Slovenia the appropriate harvesting system for a particular site is determined in the Forest management plans [8]. The key element in harvesting system selection is the forest entrepreneur, where rationality and competitiveness are the leading guidelines. The organisation of work is related to the company size (which performs forest operations) and its technological equipment. After a site inspection, a trained and experienced employee selects harvesting system, based on current working conditions and available machinery. However, when selecting the proper harvesting system for particular forest site, both economic and ecological aspects should be considered [9].

Numerous studies on nominal ground pressure of wheels and machines on forest soils were carried out in the past. Despite extensive professional work the systems for predicting deformations and their physiological consequences have remained relatively unreliable [5].

In Germany, minimum standards are determined for soil protection; i.e. in the Forestry Act, Nature Conservation Act and Soil Conservation Act [10]. Principles of appropriate forest management practices in the German Forest Act determine declaratory requirement of sustainable, careful and proper forest management: (i) maintenance of soil fertility, (ii) conservation of natural soil functions, (iii) soil and stand-friendly forest management, considering also the natural habitats of animal and plant species, (iv) demand limited and nature-friendly forest exploitation, considering also the landscape and forest function [10].

According to Owende et al. [11], the environmental impacts of mechanised harvesting operations depend on several factors such as: (i) site type, suitability of machinery to respective terrain, (ii) harvesting system, (iii) layout of the trails, and (iv) time of year during which the operations are carried out (weather conditions).

In order to meet the ecological requirements, decision tools were developed to facilitate eco-efficient harvesting techniques $[7,11,12]$. The decision tool presented by Owende et al. [11] is simple to use and consists of ground specifications (e.g. ground bearing 
capacity, ground roughness and slope) and machinery parameters (e.g. nominal ground pressure). The decision-making tool, however, does not consider the impact of soil moisture/ terrain properties. Grüll [12] and Erler and Grüll [13] presented a site-focused decisionmaking model, where the decision-making process is supported by classifying the natural value (producing capacity) of the soil, site trafficability and technical suitability of the wood harvesting procedure. The outcome was a combined ecological and technical evaluation of the procedure. The tool presented by Grüll and Erler is detailed, but on the other hand more complex and somehow difficult to implement under other conditions (i.e. in other environments and countries). Approaches using a multi-criteria decision support tool based on Multi Criteria Analysis (MCA) as presented Kühmaier and Stampfer [14] are also promising, although used to estimate a proper energy wood supply chain.

The terrain properties and soil-machine interactions [7, 11], as well as stand-machine interactions (damages to roots and remaining trees) were widely studied in the past years, with the data suitable to be used for the preparation of reliable decision-making tools. The main objective of this study was to suggest a new practical decision-making tool for selection of most suitable harvesting systems, considering terrain steepness, ground bearing capacity and soil moisture. The decision-making tool should support cost-efficient and environmentally friendly mobilisation of wood and should be easily adapted to different conditions.

\section{MATERIALS AND METHODS}

For a successful selection of suitable harvesting systems the suggested decision-making tool (DMT) includes relevant parameters such as soil and terrain characteristics and basic machine properties. The DMT variables were quantified based on studies carried out by other research groups, e.g. by Owende et al. [11].
The presented tool is bidirectional; it can be used to determine the proper harvesting system for individual sites, or vice-versa.

During the harvesting system selection process, given terrain and soil conditions should be considered. Soil damages during off-road machine operations are mostly influenced by soil properties and conditions in the moment when under load and by nominal ground pressure of machinery $[6,7]$. The preparation/adaptation of DMT to specific site conditions and harvesting systems is supposed to be carried out in three consecutive phases: (i) estimation of soil and terrain conditions, (ii) prediction of suitable harvesting systems and depiction in wood process charts ("functiogramms"), (iii) finalization of decision matrix (Figure 1).

\section{Soil Characteristics}

The strength of soils were classified based on their ground bearing capacities (GBC); i.e. capacity to support the load pressing on it. In forestry, the soil bearing capacity is usually considered as the maximum allowable wheel contact pressure. Soil bearing capacity, shear strength and penetration resistance are dependent on soil moisture, dry density and particle size distribution. However, development of universal models explaining relationships among mentioned parameters seems difficult, because both frictional and electro-chemical forces are involved in the formation of the soil strength [15]. The following soil type classes (from soft to hard) (Table 1) were adopted according to Owende et al. [11]: (i) very soft soil (GBC $\leq 40 \mathrm{kPa})$, (ii) soft soil (GBC from 40 to $60 \mathrm{kPa}$ ), (iii) average soil (GBC from 60 to $80 \mathrm{kPa}$ ) and (iv) strong soil (GBC $\geq 80 \mathrm{kPa}$ ).

It should be considered that GBC, in particular, is greatly reduced when soil is saturated with water.

One of the main criteria in selection of machinery to corresponding site condition is the wheel/soil contact pressure. It is a simplification of the vertical stress, where loaded tyre or track imposes on the soil [11]. 


\section{a) First step:}

- Define soil and terrain classes.

\section{b) Second step:}

- Define harvesting systems considering variety

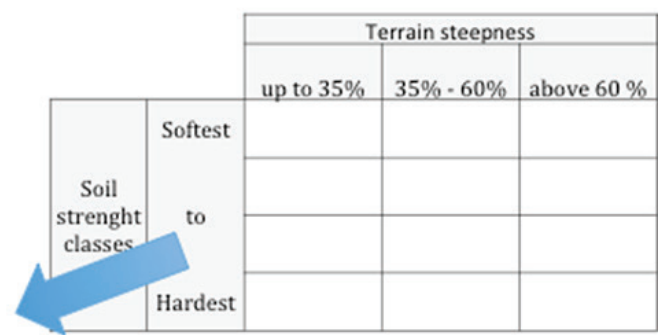
of site conditions, as well as economical aspects.

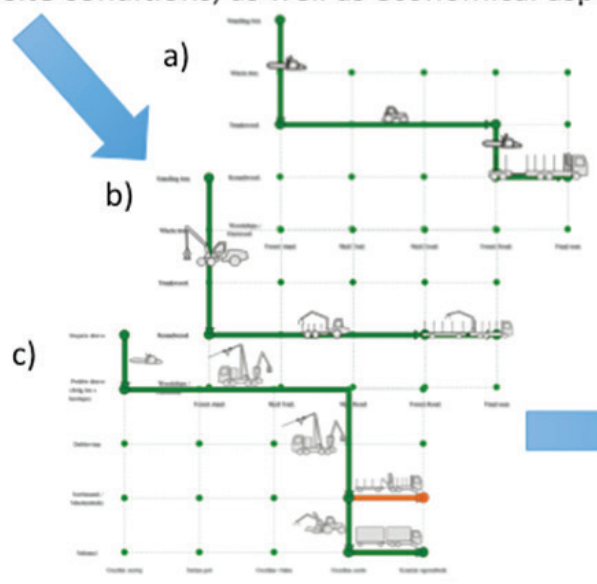

c) Final step: Complete the decision matrix with harvesting systems (defined during the second step) matching the ecological requirements (site conditions) with economical and technological requirements.

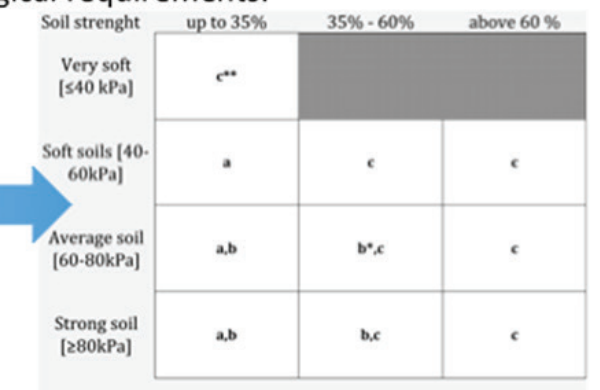

FIGURE 1. Process of building decision-making matrix

TABLE 1. Different soil strength classes

\begin{tabular}{|c|c|c|c|c|}
\hline $\begin{array}{l}\text { Soil strength } \\
\text { classes }\end{array}$ & Soil description & & $\begin{array}{l}\text { Basic soil types } \\
\text { for Croatia }\end{array}$ & $\begin{array}{l}\text { Basic soil types } \\
\text { for Slovenia }\end{array}$ \\
\hline References & Hyvärinen and Ahokas [16] & Ragot [17] & Poršinsky et al. [6] & $\begin{array}{c}\text { Urbančič et al. } \\
{[18]}\end{array}$ \\
\hline Very soft soil & $\begin{array}{l}\text { Peatland (open), Snow } \\
\text { (virgin) }\end{array}$ & & Wet peats & Peat \\
\hline Soft soil & Snow (old, -10$)$ & $\begin{array}{l}\text { Alluvial soils, } \\
\text { Peatland (open) }\end{array}$ & $\begin{array}{l}\text { Wet gleys and } \\
\text { peaty soils }\end{array}$ & Deep siliceous soil \\
\hline Average soil & Peatland (wooded) & & $\begin{array}{l}\text { Soft mineral or } \\
\text { iron-pan soils }\end{array}$ & $\begin{array}{l}\text { Deep carbonate } \\
\text { soil }\end{array}$ \\
\hline Strong soil & $\begin{array}{l}\text { Moraine, Gravel, Sand, Clay, } \\
\text { Snow (compressed, - 10C) }\end{array}$ & $\begin{array}{l}\text { Gravel, Sand, } \\
\text { Clay, Snow } \\
\text { (hardpacked, -10C) }\end{array}$ & $\begin{array}{l}\text { Dry sands and } \\
\text { gravels, Firm } \\
\text { mineral soils }\end{array}$ & Shallow soil \\
\hline
\end{tabular}

Nominal ground pressure (NGP) is widely used, easy to assess mobility variable [15], although it has the disadvantage of neglecting the influence of tyre deformation. Influence on forest floor/soil is mainly related to the wheel/ soil interaction, thus nominal ground pressure
(NGP) is less destructive on soils with higher ground bearing capacity then those with lower [15].

NGP is calculated as the ratio between the wheel load and dimension of tyres [11]:

- For wheeled machines: 


$$
N G P_{\text {wheels }}=\frac{W}{r \times b}
$$

where NGP is the nominal ground pressure in $\mathrm{kPa}, \mathrm{W}$ is wheel load in $\mathrm{kN}, \mathrm{r}$ is wheel radius in $\mathrm{m}$, and $\mathrm{b}$ is tyre width in $\mathrm{m}$.

- For tracked machines:

$$
N G P_{\text {tracks }}=\frac{W}{b}(125+L)
$$

where $\mathrm{W}$ is track load in $\mathrm{kN}, \mathrm{L}$ is the length between the wheel centres in $\mathrm{m}$, and $\mathrm{b}$ is track width in $\mathrm{m}$.

\section{Terrain Characteristics}

Nominal ground pressure on the axle depends on distribution of the mass on the vehicle, which is different on flat ground than on great slopes [19]. The research carried out by Marenče $[19,20]$ demonstrates the principles of weight transfer to the rear axis during upward hauling and transfer of loads to the front axis during downward hauling. Technical characteristics of chosen machinery are thus of vital importance when selecting harvesting systems; weight distribution on the axis greatly depends on slope of the terrain. E.g. during downward hauling the forwarder with one axis in front and two rear axis represents a specific problem since the downhill axis are under higher load (bearing two thirds of the load).

The DMT should enable the selection of harvesting system, most appropriate for particular types terrain, soil conditions at selected working/harvesting site. In order to meet specific conditions in the first step, a matrix containing terrain and soil conditions needs to be configured as exemplified in Figure 1 a.

For the purpose of this article we suggested three terrain slope classes: (i) up to $30 \%$, (ii) $31 \%-60 \%$ and (iii) above $60 \%$. The selected classes where proposed based on limitation of different technologies.

\section{Harvesting Systems}

During the second step, available and commonly used harvesting system in the region should be evaluated (Figure 1b). In the past, different approaches to visualise the harvesting systems have been developed and used [2125]. For describing of working processes and harvesting systems, Kuratorium für Waldarbeit und Forsttechnik e.V. KWF (2015) [21] presented a wood process charts ("functiogramms") that symbolizes cutting, hauling and transport in the process from the standing tree in the stand to the final product either on the forest road or at the end consumer. The idea of harvesting system visualisation has been developed and utilized by Erler and Weiß [26] and Erler and Dög [27].

To exemplify the three-step methodology, a decision-making matrix was prepared for the three selected harvesting systems: (i) chain saw - tractor, (ii) harvester - forwarder, and (iii) chainsaw - cable yarder.

Chain saw - tractor (Figure 2) is a traditional combination of motor-manual felling with chainsaw and haulage with forestry tractor. Wood cutter fells a tree and immediately afterwards follows the delimbing operation. Cutting is followed by stem wood extraction along the skid-road with forestry tractor using forest winch. The cross cutting of stems to assortments is foreseen at the storage by the side of forest road and then transported to enduser by truck and trailer.

Harvester - Forwarder (Figure 3) addresses machines for fully-mechanized harvesting. Cutting and assortment production take place along skid trail and is carried out by harvester. Cutting is followed by haulage of assortments with forwarder. After harvesting is completed, transport to end-user is foreseen.

Chainsaw - cable yarder (Figure 4) is a modern way of forest production with the possibility of the whole-tree yarding by cable line, where chainsaw operator fells a tree. The hauling from stand to forest road is done by the cable yarder, where delimbing and cross-cuting is performed by harvesting processor. After the completed yarding the transport of round wood is envisaged.

Wood process charts ("functiogramms") can be also used as a starting point for cost evaluation and estimation of environmental or ecological impacts. The Slovenian Forestry Institute developed WoodChainManager (WCM) 


\section{Costs of selected processes}

\begin{tabular}{|c|c|c|c|c|c|}
\hline Machine & Fixed costs in $\epsilon$ / year & Fixed costs in $\epsilon$ / hour & $\begin{array}{l}\text { Variable cost of fuels and } \\
\text { lubricants }\end{array}$ & $\begin{array}{l}\text { Variable costs of } \\
\text { maintenance in } € / \text { hour }\end{array}$ & $\begin{array}{l}\text { Total cost of supply chain } \\
\qquad[\epsilon / \mathrm{h}]\end{array}$ \\
\hline Chainsaw (4 kW) & $148.00 €$ & $1.35 €$ & $1.29 €$ & $1.20 €$ & $3.83 €$ \\
\hline Safety gear and cutting equipment & $111.00 €$ & $0.56 €$ & $0 €$ & $0.42 \epsilon$ & $0.98 €$ \\
\hline 4WD agricultural tractor ( $95-125 \mathrm{~kW})$ & $7668.33 €$ & $15.34 €$ & $18.67 €$ & $4.28 €$ & $38.28 €$ \\
\hline Cabine protection (complete) & $2293.33 €$ & $4.59 €$ & $0 €$ & $1.28 €$ & $5.87 €$ \\
\hline Wheel chains for mud (28-32") & $143.33 €$ & 1.796 & $0 €$ & $0.50 €$ & $2.29 €$ \\
\hline Two drum winch $(8 \mathrm{t})$ & $974.67 €$ & $3.48 €$ & $0 €$ & $2.72 \epsilon$ & $6.20 €$ \\
\hline Radio remote control & $172.00 €$ & $1.27 €$ & $0 €$ & $0.48 €$ & $1.75 €$ \\
\hline Chainsaw (4 kW) & $148.00 €$ & $1.35 €$ & 1.296 & $1.20 €$ & $3.83 €$ \\
\hline $\begin{array}{l}\text { Semi-truck with trailer and crane for roundwood } \\
(300 \mathrm{~kW})\end{array}$ & $29600.00 €$ & $29.60 €$ & $50.91 €$ & $14.80 €$ & $95.31 \epsilon$ \\
\hline
\end{tabular}

Fuel prices used for calculation: Diesel: $1.2190 €$, Petrol: $1.3230 €$

\section{Total cost of supply chain [€/ h]: $158.34 €$}

\section{Visualization of supply chain}

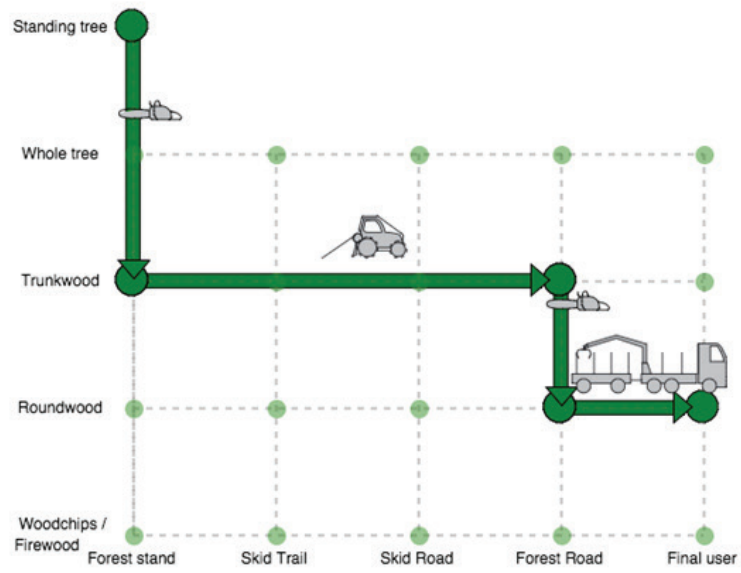

FIGURE 2. Wood process chart ("functiogramm") of motor-manual cutting and hauling with tractor harvesting system

[28] an internet tool for calculation of machinery costs [29], and visualisation of harvesting systems. Machinery costs are calculated per scheduled machine hour, where scheduled time is the time during which equipment is scheduled to do productive work [30]. Final selection of harvesting system depends on costs and productivity of selected machinery, especially in cases where soil conditions as well as terrain enable more than one option. Comparison of machinery costs along different harvesting systems facilitate the selection of suitable harvesting systems.

Evaluation of Technological, Ecological and Economic Aspects of Selected Harvesting Systems - Finalization of DMT

In the third phase, the ecological (soil and slope conditions) and technological requirements (NGP, safe slope angle, etc.) should be matched (Figure 1c). 
The main characteristics of above presented harvesting systems(Figure 2,3,4) arelisted in Table 2 , however is should be considered that these are only three from widely differing harvesting systems that can be found in the Mediterranean and SEE regions. Different systems should be analysed and included in DMT in order to match it with the accessible technology and existing environmental conditions. When proposing different harvesting systems, the evaluation by technological, ecological and economic aspects should be considered. The presented harvesting systems are limited by several constraints. For example, driving with tractor is only possible on slopes that do not exceed 35\% (very steep terrains are out of limits). On the other site, fully-mechanized harvesting system is limited with ecological aspects due to off-road driving on skid trails, their NGP exceed GBC and therefore cause damages on forest soils. Skid trails are defined as alignment in the forest, in which harvester and forwarder are moving. Cable crane yarding is limited neither with technological nor ecological aspects, but rather with economic aspects. Due to high cost of production in order to be economically efficient it is only appropriate for steep terrains with higher volumes of harvestable timber.

The presented parameters (Table 2) are the main input data to fill in the decisionmatrix. Technological and ecological aspects of harvesting machines are available in their technical description. Costs are calculated using the WCM tool [28].

\section{Costs of selected processes}

\begin{tabular}{|c|c|c|c|c|c|}
\hline Machine & Fixed costs in $€$ / year & Fixed costs in $€ /$ hour & $\begin{array}{l}\text { Variable cost of fuels and } \\
\text { lubricants }\end{array}$ & $\begin{array}{l}\text { Variable costs of } \\
\text { maintenance in } \epsilon / \text { hour }\end{array}$ & $\begin{array}{l}\text { Total cost of supply chain } \\
\qquad[€ / \mathrm{h}]\end{array}$ \\
\hline Harvester $(170 \mathrm{~kW})$ & $56616.67 €$ & $62.91 €$ & $29.69 €$ & $39.50 €$ & $132.10 €$ \\
\hline Forwarder $(140 \mathrm{~kW})$ & $48000.00 €$ & $48.00 €$ & $23.76 €$ & $30.00 €$ & $101.76 €$ \\
\hline $\begin{array}{l}\text { Semi-truck with trailer and crane for roundwood } \\
(300 \mathrm{~kW})\end{array}$ & $29600.00 €$ & $29.60 €$ & $50.91 €$ & $14.80 €$ & $95.31 \epsilon$ \\
\hline
\end{tabular}

Total cost of supply chain [€/ h]: $329.16 €$

\section{Visualization of supply chain}

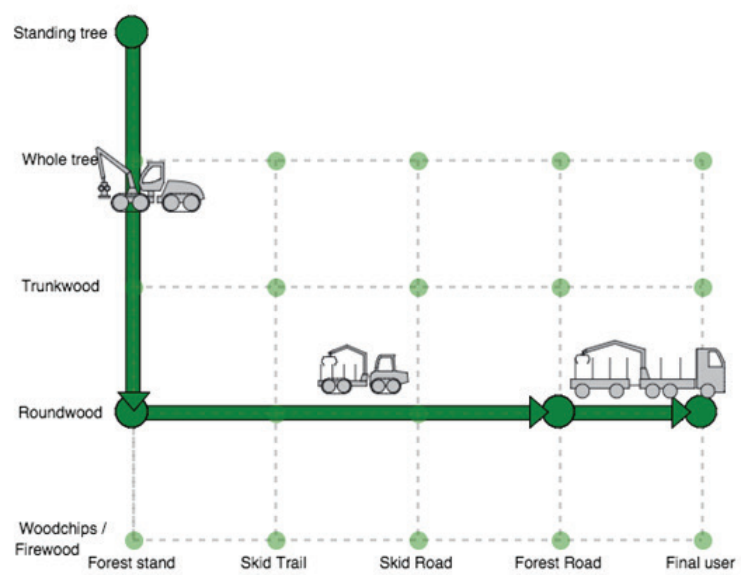

FIGURE 3. Wood process chart ("functiogramm") of fully-mechanized harvesting system 
TABLE 2. Selected aspects important for DMT

\begin{tabular}{|c|c|c|c|c|c|c|c|}
\hline \multicolumn{2}{|c|}{ Harvesting system } & \multicolumn{2}{|c|}{ Ecological aspect } & \multicolumn{2}{|c|}{ Technology aspect } & \multicolumn{2}{|c|}{ Economical aspect } \\
\hline $\begin{array}{l}\text { Harvesting } \\
\text { system }\end{array}$ & Machinery & $\begin{array}{l}\text { Gross mass } \\
\text { (kN) }\end{array}$ & $\mathrm{NGP}(\mathrm{kPa})$ & $\begin{array}{l}\text { Max. slope } \\
\text { (\%) }\end{array}$ & $\begin{array}{l}\text { Engine power } \\
(\mathrm{kW})\end{array}$ & $\begin{array}{l}\text { Cost } \\
\left(€ \cdot h^{-1}\right)\end{array}$ & $\begin{array}{l}\text { Productivity } \\
\left(\mathrm{m}^{3} \cdot 8 \mathrm{~h}^{-1}\right)\end{array}$ \\
\hline \multirow{2}{*}{$\begin{array}{l}\text { a) Chain } \\
\text { saw - tractor }\end{array}$} & Chainsaw & NR & NR & - & 4 & 3.78 & 15 \\
\hline & $\begin{array}{l}\text { Tractor with } \\
\text { winch }\end{array}$ & 65 & 117 & $<35$ & 110 & 41.89 & 25 \\
\hline \multirow[b]{2}{*}{$\begin{array}{l}\text { b) Harvester - } \\
\text { Forwarder }\end{array}$} & Harvester (12t) & 132 & 54 & $<60$ & 140 & 118.73 & 70 \\
\hline & Forwarder (12t) & 230 & $\begin{array}{c}55 \text { (front } \\
\text { tyres), } \\
100 \text { (back } \\
\text { tyres) }\end{array}$ & $<60$ & 140 & 101.33 & 60 \\
\hline \multirow{3}{*}{$\begin{array}{l}\text { c) Chainsaw - } \\
\text { cable yarder }\end{array}$} & Chainsaw & NR & NR & - & 4 & 3.78 & 15 \\
\hline & $\begin{array}{l}\text { Cable crane } \\
\text { mounted on } \\
\text { truck with } \\
\text { processor head }\end{array}$ & NR & NR & - & 300 & 413.99 & 80 \\
\hline & $\begin{array}{l}\text { Chipper } \\
\text { powered by } \\
\text { agricultural } \\
\text { tractor }\end{array}$ & NR & NR & $<30$ & 110 & 112.05 & 80 \\
\hline
\end{tabular}

NR - not relevant

\section{Costs of selected processes}

\begin{tabular}{|c|c|c|c|c|c|}
\hline Machine & Fixed costs in $\epsilon /$ year & Fixed costs in $\epsilon$ / hour & $\begin{array}{l}\text { Variable cost of fuels and } \\
\text { lubricants }\end{array}$ & $\begin{array}{c}\text { Variable costs of } \\
\text { maintenance in } \epsilon / \text { hour }\end{array}$ & $\begin{array}{c}\text { Total cost of supply chain } \\
{[\epsilon / \mathrm{h}]}\end{array}$ \\
\hline Chainsaw (4 kW) & $148.00 €$ & $1.35 €$ & $1.29 €$ & $1.20 €$ & $3.83 €$ \\
\hline Safety gear and cutting equipment & $111.00 €$ & $0.56 €$ & o€ & $0.42 €$ & $0.98 €$ \\
\hline $\begin{array}{l}\text { Cable crane mounted on truck with processor } \\
\text { head }\end{array}$ & $83200.00 €$ & $104.00 €$ & $50.91 €$ & $260.00 €$ & $414.91 €$ \\
\hline $\begin{array}{l}\text { Semi-truck with trailer and crane for roundwood } \\
(300 \mathrm{~kW})\end{array}$ & $29600.00 €$ & $29.60 €$ & $50.91 €$ & $14.80 €$ & $95.31 €$ \\
\hline
\end{tabular}

Total cost of supply chain $[€ / \mathrm{h}]: 515.02 €$

Visualization of supply chain

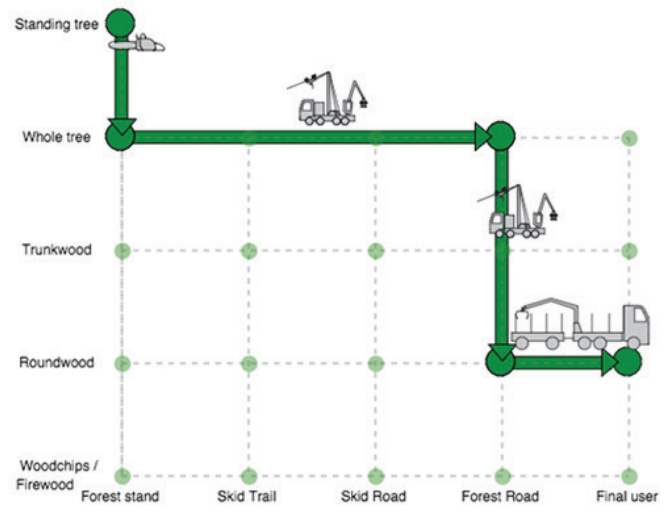

FIGURE 4. Wood process chart ("functiogramm") of cable crane yarding harvesting system 


\section{RESULTS}

\section{Preparation of the Decision-Making Matrix}

The three above presented harvesting systems, i.e. motor manual harvesting system (Figure 2), Harwarder - Forwarder harvesting system (Figure 3) and cable crane yarding harvesting system (Figure 4) were inserted into the matrix (Figure 5), following the requirements and limitations described above. For example, the traditional motor-manual harvesting (Figure 2) has technological limitation as described above and the only ecological limitation that needs to be considered are very soft soils with low GBC. In case of fully mechanized harvesting (Figure 3), ecological requirements are the limiting factor, thus measures to lower site impact should be considered for example for sites with low ground baring capacity (e.g. using of the boogie tracks, carrying only half loads, etc.). The unconventional cable crane yarding (Figure 4) is in accordance with ecological and technological requirements and suitable for all proposed site conditions, but due to economical limitation (high production cost) applicable only where no other harvesting system can be applied or at high productive working sites.

\section{Example of Decision-Making Matrix Developed for Slovenian Conditions}

The above presented DMT is differing from the one developed for Slovenia in two aspects. In the Slovenian matrix the ordinate axis defines different soil type and therefore two moisture categories (damp and dry soils) where introduced. Since in the above presented DMT soil types where replaced by GBC classes the soil moisture parameter is redundant. A decisionmatrix developed for Slovenian conditions is containing more than 12 different technological solutions (Figure 6). The matrix includes harvesting systems from cable crane yarding (1), combinations of motor-manual harvesting (24), different combinations of fully mechanized

\begin{tabular}{|c|c|c|c|}
\hline Soil strenght & up to $35 \%$ & $35 \%-60 \%$ & above $60 \%$ \\
\hline $\begin{array}{l}\text { Very soft } \\
{[\leq 40 \mathrm{kPa}]}\end{array}$ & $\mathbf{c}^{* *}$ & & \\
\hline $\begin{array}{l}\text { Soft soils [40- } \\
\quad 60 \mathrm{kPa}]\end{array}$ & a & c & c \\
\hline $\begin{array}{c}\text { Average soil } \\
{[60-80 \mathrm{kPa}]}\end{array}$ & $\mathbf{a}, \mathbf{b}$ & $\mathbf{b}^{*}, \mathbf{c}$ & c \\
\hline $\begin{array}{c}\text { Strong soil } \\
{[\geq 80 \mathrm{kPa}]}\end{array}$ & $\mathbf{a}, \mathbf{b}$ & b,c & c \\
\hline
\end{tabular}

\section{Remarks:}

a stand for motor-manual cutting and hauling with tractor harvesting system (Figure 2)

b stand for fully-mechanized harvesting system (Figure 3)

c stand for cable crane yarding harvesting system (Figure 4)

* stand for using additional equipment (i.e. using fitted boogie tracks on harvester or forwarder)

** stand for additional cost consideration

FIGURE 5. Decision-making matrix 


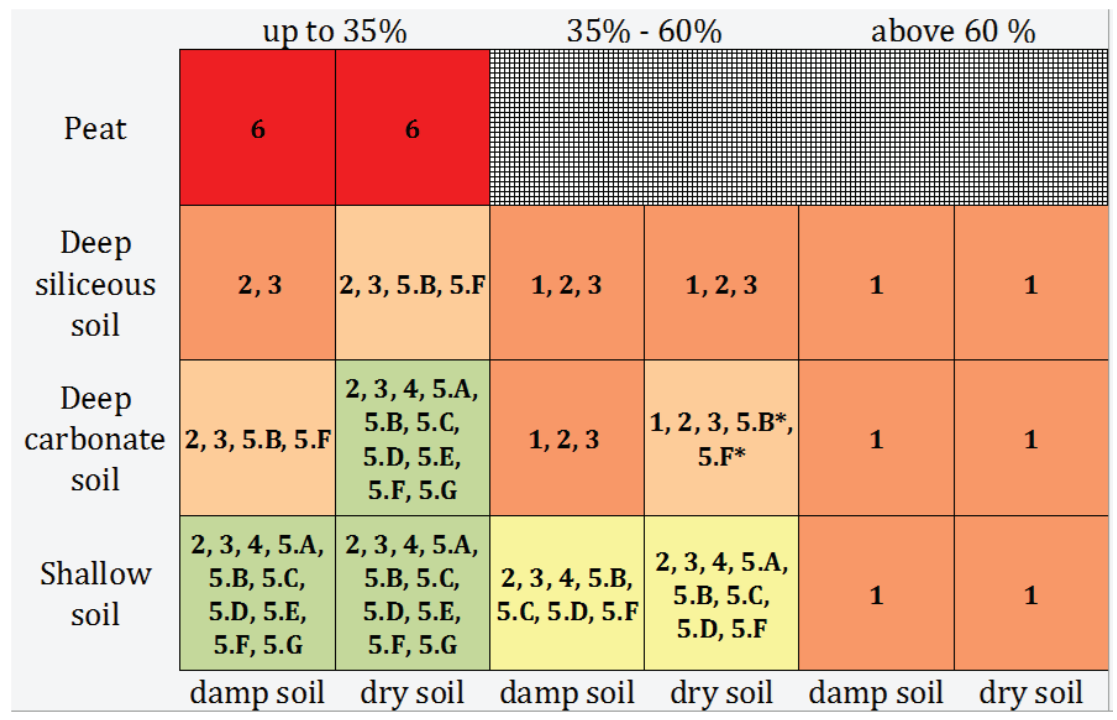

Legend:

1-6 stands for harvesting systems from cable crane yarding (1), combinations of motor-manual harvesting (2-4), different combinations of mechanized harvesting (5) to helicopter yarding (6). Harvesting systems cannot be directly matched to the systems described in figure 5 as they are focusing onto a woodchip production.

5.A represent fully mechanized harvesting systems with large machines (according to FHP 2010).

5.B represent fully mechanized harvesting systems with large machines (according to FHP 2010) with fitted caterpillar to its boggie axles.

5.C represent fully mechanized harvesting systems with medium-sized machines (according to FHP 2010).

5.D represent fully mechanized harvesting systems with small machines (according to FHP 2010).

5.E represent fully mechanized harvesting systems with smallest machines (according to FHP 2010).

5.F represent partly mechanized harvesting systems where felling is partly done using chainsaw.

5.G represent fully mechanized harvesting systems where forwarder is equipped with chipper (and chips container).

* Technologies suitable only on slopes from $35 \%-40 \%$

FIGURE 6. Decision-making tool for the selection of suitable harvesting system in Slovenian conditions

harvesting (5) to helicopter yarding (6), although not common in Slovenia, applicable in extreme conditions. The methodology and DMT were developed within a national project with the main aim to provide forest operators and forest managers with a simple planning tool. The final project report includes a detailed description of all harvesting system in order to facilitate the decision process of forest operators [31].

\section{DISCUSSION}

With the changes due to increased fullymechanized harvesting the efficiency of forest production have changed. Together with them, the impacts of these technologies on forests have changed as well. The expensive modern machines require suitable training of not only machinists but executive and technical personnel [32] as well. In the case of mechanized cutting, the machinist's suitable qualification is of exceptional importance from the aspect of potential damages caused to forest stands [33]. Presented decision-making tool could be used as a part of regular training for forest operators.

The decision-making tool is applicable for planning of forest production on concrete working sites (harvesting sites). Primarily, the decision-making should simplify the analysis/ evaluation of forest operations, although it can also be advantageously used during the execution of work, when working conditions change: 
- changed humidity conditions at working site,

- machine has broken down and has to be replaced with a new one,

- to fill the capacities, another/unforeseen machine is used.

The decision-making tool supports the planning of harvesting operations. Since there is no uniform decision making matrix for all different types of soils or different harvesting systems, DMT can be prepared individually and with region-specific technology.

Considering the predicted quantities and types of forest wooden assortments, it is possible to use the DMT for a basic selection of most appropriate harvesting systems. It is designed in such a way that a new harvesting system can be added at any time.

\section{CONCLUSIONS}

The decision-making tool for evaluating harvesting systems was developed on the basis of foreign experience and own studies concerning the green woodchips supply chain carried out in a national research project. The presented methodology serves as a guideline for preparation of region specific DMT for selection of most appropriate harvesting systems in the phase of silvicultural planning as well as in the phase of forest operations planning or operational work management. The developed tools should be checked in practice and supplemented in the sense of practical utility. Economic aspects of different harvesting system can be easily estimated using WoodChainManager, an internet tool that is based on FAO methodology for machinery cost calculation and also enables visualisation of harvesting system.

\section{Acknowledgements}

The study was supported and carried out within the framework of the following international and national projects: PROFORBIOMED (1S-MED10-009), NEWFOR, SmartLogChains (IPA A/SLO) and PER-LES. We would like to thank the anonymous reviewers for their valuable comments and suggestions for improving the quality of the paper.

\section{REFERENCES}

1. BOURIAUD O, ŞTEFAN G, FLOCEA M 2013 Predictive models of forest logging residues in Romanian spruce and beech forests. Biomass Bioenerg 54: 59-66. DOI: http://dx.doi.org/10.1016/j.biombioe.2013.03.022

2. MAGAGNOTTI N, SPINELLI R, GÜLDNER O, ERLER J 2012 Site impact after motor-manual and mechanised thinning in Mediterranean pine plantations. Biosyst Eng 113 (2): 140-147. DOI: http:// dx.doi.org/10.1016/j.biosystemseng.2012.07.001

3. MAGAGNOTTIN, PICCHI G, SPINELLI R 2013 A versatile machine system for salvaging small-scale forest windthrow. Biosyst Eng 115 (4): 381-388. DOI: http:// dx. doi.org/10.1016/j. biosystemseng.2013.05.003

4. SPINELLI R, MAGAGNOTTI N 2011 The effects of introducing modern technology on the financial, labour and energy performance of forest operations in the Italian Alps. Forest Policy Econ 13 (7) : 520-524. DOI: http://dx.doi.org/10.1016/j.forpol.2011.06.009
5. MIHELIČ M 2014 Economy and environmental aspects of forest harvesting for energy biomass. PhD thesis, University of Ljubljana, Biotechnical Faculty, Ljubljana, Slovenia, 285 p

6. PORŠINSKY T, PENTEK T, BOSNER A, STANKIĆ I 2012 Ecoefficient Timber Forwarding on Lowland Soft Soils. In: Okia CA (ed) Global Perspectives on Sustainable Forest Management. InTech, Rijeka, Croatia, pp 275-288. DOl: http://dx.doi.org/10.5772/34687

7. PORŠINSKY T, STANKIĆ I, BOSNER A 2011 Ecoefficient Timber Forwarding Based on Nominal Ground Pressure Analysis (in Croatian with English summary). Croat J For Eng 32 (1): 345-355

8. MKGP, MOP 2010 Pravilnik o načrtih za gospodarjenje z gozdovi in upravljanje $z$ divjadjo (in Slovenian). Uradni list RS 91/2010, Ljubljana, Slovenia. URL: http://www.uradni-list.si/1/objava. jsp? urlurid $=20104838 \quad(20 \quad$ January $\quad 2015)$ 
9. ROBEK R 2011 Pridobivanje lesa (in Slovenian). In: Medved M (ed) Gospodarjenje z gozdom za lastnike gozdov. Kmečki gals, Ljubljana, Slovenia, pp 204-247

10. GRÜLLM2014GrundlagenfüreinBodenschutzkonzept des Landesbetriebs Forst Brandenburg (in German). Eberswalder Forstliche Schriftenreihe 55: 49-58

11. OWENDE $P$, LYONS J, HAARLAA R, PELTOLA $A$, SPINELLI R, MOLANO J, WARD S 2002 Operations protocol for eco-efficient wood harvesting on sensitive sites. Ecowood Partnership, Dublin, Ireland, 74 p. URL: http://www.ucd.ie/foresteng/ html/ecowood/op.pdf (20 January 2015)

12. GRÜLL M 2011 Den Waldboden schonen Vorsorgender Bodenschutz beim Einsatz von Holzerntetechnik (in German). Eberswalder Forstliche Schriftenreihe 47: 37-44

13. ERLER J, GRÜLL M 2008 Standortgerechte Holzernteverfahren - ein Beitrag zur Harmonisierung von biologischer und technischer Produktion (in German). FTI 3-4: 36-40

14. KÜHMAIER M, STAMPFER K 2012 Development of a multi-criteria decision support tool for energy wood supply management. Croat J For Eng 33 (2): 181-198

15. SAARILAHTI M 2002 Soil interaction model. In: Development of a protocol for ecoefficient wood harvesting on sensitive sites (ECOWOOD) - project deliverable. University of Helsinki, Department of Forest Resource Management, Helsinki, Finland, 87 p. URL: http://ethesis.helsinki.fi/julkaisut/maa/ mvaro/publications/31/soilinte.pdf (20 January 2015)

16. HYVÄRINEN H, AHOKAS J 1975 The stability of framesteered forest machines(in Finnish). Finnish Research Institute of Engeneering in Agriculture and Forestry, Helsinki, Finland, $31 \mathrm{p}$

17. RAGOT MJ 1976 Matériels et techniques de débardage a l'aide de véhicules a roues (in French). Cahiers du Centre Technique du Bois, Paris, France, 64 p

18. URBANČIČ $M$, SIMONČIČ $P$, PRUS T, KUTNAR L 2005 Atlas gozdnih tal Slovenije (in Slovenian). Zveza gozdarskih društev Slovenije, Gozdarski vestnik. Gozdarski inštitut Slovenije, Ljubljana, Slovenia 100 p

19. MARENČE J 2005 Changes in technical parameters of tractors in timber skidding - a criterion for selecting work equipment. PhD thesis, University of Ljubljana, Biotechnical Faculty, Ljubljana, Slovenia, 271 p

20. MARENČE J 2000 Ugotavljanje tehničnih parametrov traktorja Woody 110 (metodologija in merilni inštrumenti) (in Slovenian). In: Potočnik I (ed)
Gozdarski študijski dnevi. Univerza v Ljubljani Biotehniška fakulteta, Oddelek za gozdarstvo in obnovljivegozdnevire, Ljubljana, Slovenia, pp209-228

21. ERLER J 2015 Funktiogramme - Darstellung von Holzernteverfahren auf einen Blick (in German). Kuratorium für Waldarbeit und Forsttechnik e.V., Groß-Umstadt, Germany. URL: http://www.kwf-online.org/arbeitsverfahren/ funktiogramme.html (20 January 2015)

22. MORAT J, FORBIG A, GRAUPNER J 1998 Holzernteverfahren: Vergleichende Erhebung und Beurteilung der Holzernteverfahren in der Bundesrepublik Deutschland (in German). Nr. 25/ 1998. KWF. Gross-Umstafst., 110p

23. STAAF A 1972 Drivning - avverkning och transport i skogsbruket (in Swedish). LTs förlag, 444 p

24. KOŠIR B. 1997. Pridobivanje lesa (in Slovenian). Študijsko gradivo. Univerza v Ljubljani, Biotehniška fakulteta, Oddelek za gozdarstvo in obnovljive gozdne vire, Ljubljana, 330 p

25. FOREST ENERGY PORTAL 2015 Supply Chain Illustrations. URL: http://www.forestenergy. org/pages/images/ (20 March 2015)

26. ERLER J, WEIß M 2003 Netz-Darstellung von Arbeitsverfahren (in German). FTI 54 (9): 103-107

27. ERLER J, DÖG M 2009 Funktiogramme für Holzernteverfahren (in German). FTI (9-10): 14-17

28. TRIPLAT M, KRAJNC N, DOLENJŠEK M 2014 WoodChainManager. Slovenian Forestry Institute, Ljubljana, Slovenia. URL: http:// wcm.gozdis.si/\# (20 January 2015)

29. FAO 1992 Cost Control in Forest Harvesting and Road Construction. Forestry papers Nr. 99. Food and Agriculture Organization of the United Nations, Rome, Italy, 16 p. URL: http://www.fao.org/docrep/ T0579E/T0579E00.htm\#Contents (20 January 2015)

30. BRINKER RW, KINARD J, RUMMER B, LANFORD B 2002 Machine Rates for Selected Forest Harvesting Machines. Alabama Agricultural Experiment Station, Auburn University, Auburn, Alabama, USA, 32 p

31. TRIPLAT M, KRAJNC N, ROBEK R 2014 Selection of technological system in the production of green woodchips. Slovenian forestry institute, Ljubljana, Slovenia, $37 \mathrm{p}$

32. KOŠIR B 2010 Gozdna tla kot usmerjevalec tehnologij pridobivanja lesa (in Slovenian). Univerza v Ljubljani, Biotehniška fakulteta, Oddelek za gozdarstvo in obnovljive gozdne vire, Ljubljana, Slovenia, 80 p 